NBER WORKING PAPER SERIES

\title{
WHY A FUNDED PENSION SYSTEM IS USEFUL AND WHY IT IS NOT USEFUL
}

\author{
Hans-Werner Sinn \\ Working Paper 7592 \\ http://www.nber.org/papers/w7592 \\ NATIONAL BUREAU OF ECONOMIC RESEARCH \\ 1050 Massachusetts Avenue \\ Cambridge, MA 02138 \\ March 2000
}

This paper was presented in a plenary session of the 55 $5^{\text {th }}$ IIPF Congress in Moscow, 23-26 August 1999. I gratefully acknowledge careful research assistance by Marcel Thum and Jakob von Weizsacker, who helped calculate figures 1 and 2 . The views expressed herein are those of the authors and are not necessarily those of the National Bureau of Economic Research.

(C) 2000 by Hans-Werner Sinn. All rights reserved. Short sections of text, not to exceed two paragraphs, may be quoted without explicit permission provided that full credit, including (C) notice, is given to the source. 
Why a Funded Pension System is Useful and Why It is Not Useful

Hans-Werner Sinn

NBER Working Paper No. 7592

March 2000

JEL No. H5

\begin{abstract}
Based on explicit present value calculations, the paper criticizes the view that the PAYGO system wastes economic resources. In present value terms, there is nothing to be gained from a transition to funded system even though the latter offers a permanently higher rate of return. The sum of the implicit and explicit tax burdens that result from the need to respect the existing pension claims is the same under all systems and transition strategies. Nevertheless a partial transition to a funded system may be a way to overcome the current demographic crisis because it replaces missing human capital with real capital and helps smooth tax and child reading costs across the generations.
\end{abstract}

Hans-Werner Sinn

Schackstasse 5

80539 Munich

GERMANY

CESifo and NBER

hws@ces.vwl.uni-muenchen.de 


\section{Introduction}

Should the pay-as-you-go pension system (PAYGO system) be replaced with a funded system, and if so, why? Many authors have expressed many different opinions on this problem, and the matter has been analyzed within highly sophisticated theoretical and empirical models. Some authors, like Feldstein (1995), Kotlikoff, Smetters, and Walliser (1998), Feldstein and Samwick (1998) or Börsch-Supan (1998) and, most notably, Homburg (1990, 1997), have constructed models that generate efficiency gains from a transition to a funded system. Others, like Fenge (1995, 1997), Brunner (1996), Sinn (1997, 1998a), the Council of Advisors to the German Ministry of Economics (Wissenschaftlicher Beirat beim Bundesministerium für Wirtschaft 1998), and Geanakopolos, Mitchell, and Zeldes (1998), some of whom were inspired by seminal articles of Lüdeke (1988) and Breyer (1989), have argued that a Pareto improving transition to a funded system is not possible.

This paper will not try to reinvent the wheel, but it can, and will, do two things.

First, it will offer a set of explicit formal present value comparisons between the two systems which are, broadly speaking, in the spirit of the German debate about pension reform from Lüdeke and Breyer to the Council of Advisors, but have not, to the best of the author's knowledge, been formally derived before (though they cover the classroom material the author usually presents in his lectures on social policy at the University of Munich). The comparisons will make it clear which arguments the advocates of a funded system should not use to defend their case.

Second, the paper will offer another reason why funding pensions might be useful. This reason relates to the imminent crises of the pension systems of the western world and the lack of human capital formation. 


\section{A False Reason for Advocating the Funded System}

The most frequent reason given in the public policy debate for a funded system is the apparently superior performance of the capital market in terms of the rate of return on investment it can offer. Indeed, many studies have shown how poor the rate of return on PAYGO pension contributions really is.

The result of a study carried out by the Center for Economic Studies for the Council of Advisors to the German Ministry of Economics ${ }^{1}$ is illustrated in figure 1. In that study the real internal rates of return for alternative age cohorts of average German pension contributors were calculated. The cohorts enter the system at the age of 20 and contribute continually thereafter. Their rate of return is shown for the respective entrance years, where 1957 is the year when the 'dynamic' pension system was introduced in Germany. Some members of the cohort die before they receive a pension, some receive disability pensions, some receive old age pensions. Some leave widows and orphans who then receive pensions. In theory, the rate of return should equal the rate of growth of the sum of wages, and the figure shows that this is roughly true if the compound annual growth rate over a 50 year period starting at the respective entrance year is taken as a yardstick. In the calculations up to 1997 actual growth data were used and thereafter an annual increase in the wage rate of $2 \%$, coupled with the medium demographic forecast of the Federal Statistical Office, was assumed.

The figure also shows the compound annual rate of interest of a repeated investment in ten year German government bonds over a period of 50 years starting at the time a cohort enters the pension system. Up to 1997 true data were used and for the subsequent years an interest rate of $4 \%$ which is less than the actual rate in the decades before that date was assumed. Obviously, the rate of return offered by the statutory pension insurance system is significantly lower than that offered by the capital market. Those who entered the system at

\footnotetext{
${ }^{1}$ Wissenschaftlicher Beirat beim Bundesministerium für Wirtschaft (1998) and Sinn (1999).
} 
the age of 20 when it was founded in 1957 and who will receive their pensions in the year 2002 would have been able to earn a return of $4.2 \%$ in the capital market, but the PAYGO system just gives them $2.8 \%$. And those who enter now will not receive more than $1.5 \%$, while there is no reason to believe that the capital market will generate a return lower than the one it delivered in the past, that is, a good $4 \%$.

Figure 1: The internal rate of interest in the

German statutory pension insurance system (SPI)

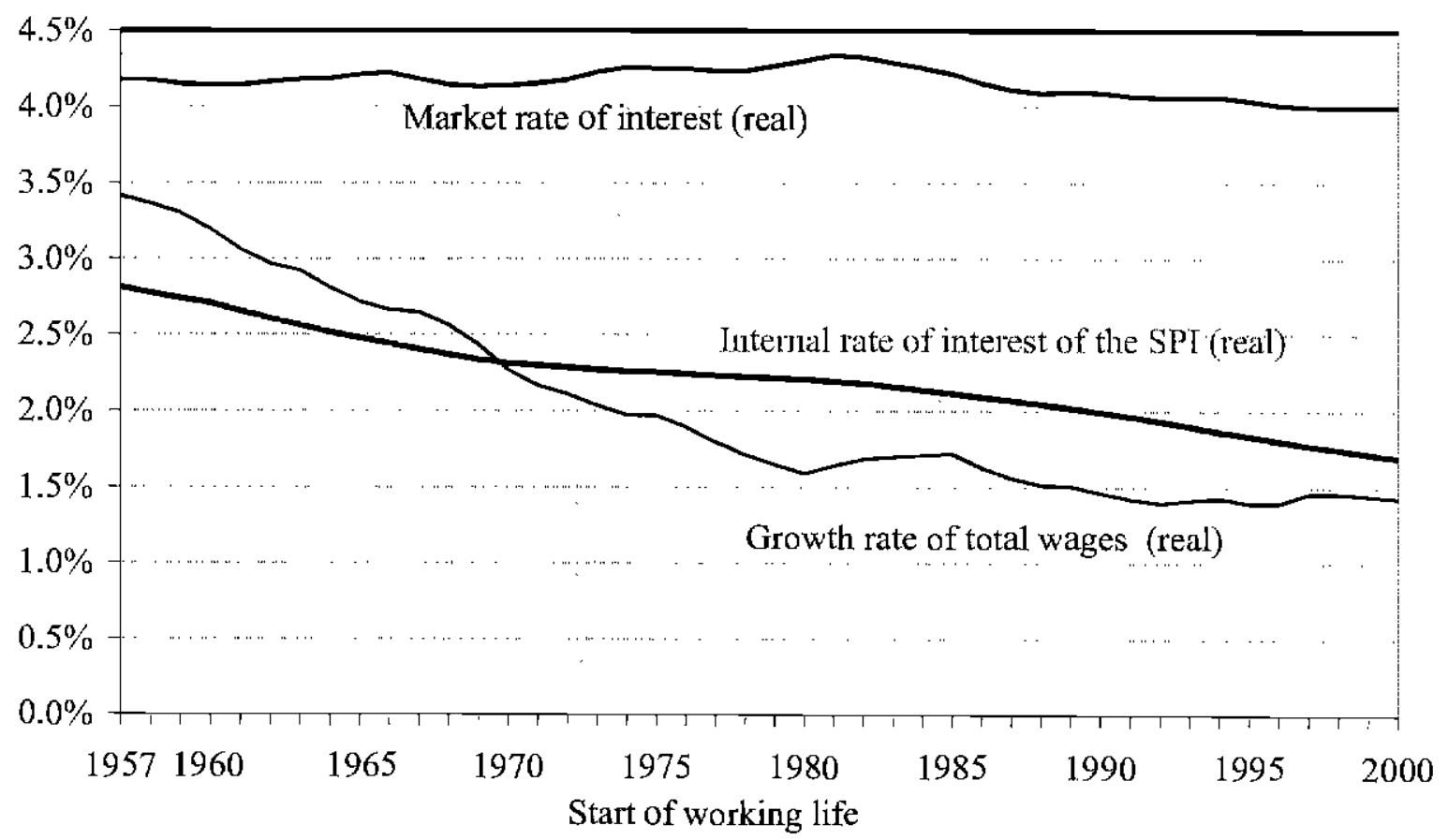

Source: $C E S$

There is no doubt that the PAYGO system offers a much lower rate of return than the capital market does. Many observers have interpreted this fact as a sign of a fundamental intrinsic inefficiency of the PAYGO system and have therefore advocated a transition to a funded system so as to make use of the higher rate of return that the capital market can offer. However, as the Council pointed out, following the basic insight of Lüdeke (1988), this interpretation is clearly too simple, since the low rate of return of the PAYGO system may 
just be the mirror image of the introductory gains of older cohorts which in 1957 were able to enter the system under overly favorable conditions. ${ }^{2}$ The PAYGO system is a device that redistributes wealth from later generations to introductory generations, but it may not essentially be an institution that wastes economic resources.

Once the introductory gains have been distributed in a PAYGO system, it may be difficult, if not impossible, to design a Pareto improving transition to a funded system. It is true that there is a burden imposed on later generations as shown by the rate of return disadvantage, but, unless the existing pension claims are negated, there may be no way to get rid of this burden and enjoy true efficiency gains.

Sinn (1997, p. 6, equation 1) has expressed this view in present value terms. He argues that "any pension system, be it PAYGO or funded or a combination of the two, is a zero-sum game for all the generations participating in the sense that the present value of all contributions equals the present value of all pensions" and he concludes that the feasible reform alternatives should be seen as devices for altering the time path of the burden imposed on later generations which are unable to reduce the size of this burden. ${ }^{3}$ In the following, this interpretation will be extended and used to derive a number of equivalence results that may help illuminate the matter.

\section{Implicit Taxes, Implicit Savings and Implicit Government Debt}

Assume an overlapping generations structure where in period $t$ there are $N_{i}^{y}$ young persons who work and $N_{t}^{p}$ pensioners who don't. The contribution to the PAYGO system of a young person is $C_{t}$ and the per capita pension received by a member of the old generation is $P_{i}$. The

\footnotetext{
${ }^{2}$ Cf. also Breyer (1989), Fenge (1995), and Homburg (1990, 1997),

${ }^{3}$ The same interpretation has been given by Geanakopolos, Mitchell, and Zeldes (1998, pp.14-15, esp. fn. 17) and Wissenschaftlicher Beirat beim Bundesministerium für Wirtschaft (1998, pp. 19-20). Cf. also Sinn (1998a).
} 
two fundamental assumptions characterizing a simple PAYGO model are that contributions are fully used to finance the pensions in the same period,

$$
N_{i}^{y} C_{1}=N_{i}^{p} P_{t}
$$

and that today's contributors are tomorrow's pensioners:

$$
N_{t}^{y}=N_{i+1}^{p}
$$

The pension claims of the old generation should, as has often been argued, be seen as an "implicit government debt":

$$
D_{1}=N_{1}^{p} P_{1}
$$

The debt has to be serviced in a similar way to the explicit debt. The difference, however, is that servicing this debt with the contribution $C_{t}$ generates a new pension claim against the next generation.

The claim against the next generation may or may not be overpaid with the contribution when compared with the price of a similar pension claim in the capital market. Call the part of the contribution that would have been sufficient to buy the PAYGO pension in the capital market 'implicit saving', $S_{t}$, and the remainder 'implicit tax', $T_{1}$ :

$$
C_{1}=S_{i}+T_{i}
$$

Obviously implicit saving is given by the equation 


$$
S_{l} \equiv \frac{P_{i+1}}{1+r_{t+1}},
$$

where $r_{t+1}$ is the rate of return offered by the capital market for an investment in $t$ that generates a return in $t+1$. The implicit tax is defined according to (4) as a residual. It is the part of the contribution which would not have been necessary if the pension claim had been bought in the capital market and which is lost from the contributor's point of view. ${ }^{4}$

\section{The Implicit Tax and the Internal Rate of Return}

Consider first the relationship between the implicit tax and the internal rate of return of the PAYGO system. Let $i_{t+1}$ denote the internal rate of return enjoyed by the pensioners of period $t+1$. As this rate is implicitly defined such that it makes a person's discounted pension equal to his contribution,

$$
C_{,} \equiv \frac{P_{t+1}}{1+i_{t+1}}
$$

Aaron's (1966) well-known equation

$$
i_{t+1}=\frac{C_{t+1} N_{i+1}^{y}}{C_{t} N_{t}^{y}}-1
$$

which shows that the internal rate of return is given by the growth rate of the aggregate pension or contribution volume can be derived from (1) and (2). 
Let

$$
\tau_{1} \equiv \frac{T_{1}}{C_{i}}
$$

indicate the implicit tax share in a person's contributions. Using (4), (5), (1) and (2) it follows that

$$
\tau_{t}=1-\frac{C_{t+1} N_{t+1}^{y}}{C_{t} N_{t}^{y}\left(1+r_{t+1}\right)}
$$

or, using (6) and rearranging terms,

$$
\tau_{t}=\frac{r_{t+1}-i_{i+1}}{1+r_{t+1}}
$$

This equation, which was also used by Lüdeke (1988, p. 171) and Homburg (1997, p. 240), says that a generation has to pay an implicit tax with its pension contributions if the internal rate of return provided by the PAYGO system - the growth rate of the aggregate pension volume - is smaller than the market rate of interest. ${ }^{5}$

In the long run, the growth rate of aggregate pensions will certainly not be able to exceed the growth rate of GDP and the latter will be less than the rate of interest if the economy converges toward a steady state to the left of the golden rule point, as it must if an intertemporal general equilibrium is to exist. ${ }^{6}$ Also, as was shown in figure 1 and observed by many authors, the internal rate of return of the pension system empirically tends to be much

\footnotetext{
${ }_{5}^{4}$ See section 7.3 for a further discussion of this point.

${ }^{5}$ Note that the two rates of return showing up in equation (7) do not refer to years but to generations, which means that they are much higher than the respective annual rates. See figure 2 for the resulting size of the implicit tax rate.

${ }^{6}$ See Sinn (1980, condition (29)). Niehans (1966) and Homburg (1991) have shown that the availability of a fixed asset such as land rules out inefficient market solutions.
} 
lower than the market rate of interest. Thus a positive tax share should be considered the normal case. Nevertheless, it is clearly possible that generous pension reforms, which imply a sufficiently strong growth in the share of wages contributed to the pension system, make the growth rate of the contributions temporarily bigger than that of the sum of wages or GDP. In this case, the implicit tax could be negative for one or more generations, and the implicit saving could exceed the pension contribution. All propositions to be derived below are compatible with this possibility. It is assumed, however, that the implicit tax rate will be strictly positive beyond some finite point in time.

How large is the implicit tax share under realistic conditions? The data used to construct figure 1 can also be used to calculate this share in the described annual cohort model for Germany which follows the spirit of the model presented here. The result is shown in figure 2.

Figure 2: The saving and tax shares in the contributions to the German statutory pension system for cohorts with alternative starting years

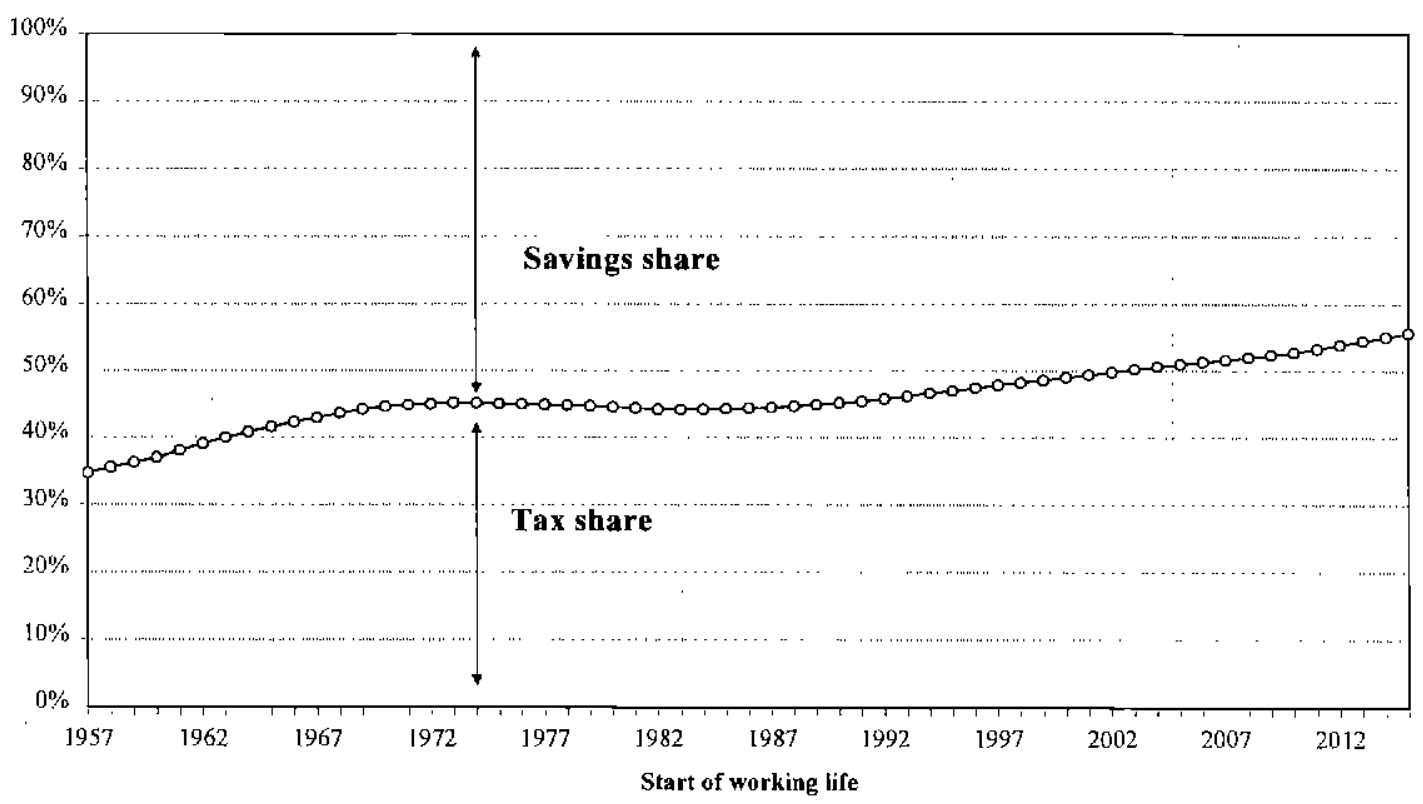


Obviously, the current German pension system has always been characterized by a positive tax share in the contributions for those who entered the system under regular conditions. The share was about one third for participants who entered the system at the age of 20 in the foundation year 1957, but, with the passage of time, the situation has significantly deteriorated for the contributors. Today, new entrants must envisage that about $50 \%$ of their pensions will be taxed away by the government to pay for the introductory gains made by those who were able to enjoy the benefits of the system without making the appropriate contributions. The situation will be even worse in future. The tax share in the contributions will rise towards $60 \%$ in the second decade of the $21^{\text {st }}$ century. ${ }^{7}$

\section{The Present Value of the Implicit Tax}

How does the implicit tax relate to the implicit government debt? To answer this question, substitute for $P_{t+1}$ in equation (5) according to (1) (where $t$ is replaced with $t+1$ ) and multiply both sides of the equation with $N_{t}^{y}$ taking account of equation (2). This gives

$$
S_{i} N_{t}^{y}=\frac{N_{i+1}^{y} C_{t+1}}{1+r_{t+1}}
$$

or, when $C_{t+1}$ is replaced according to (4):

$$
S_{i} N_{i}^{y}=\frac{T_{t+1} N_{t+1}^{y}}{1+r_{t+1}}+\frac{S_{t+1} N_{i+1}^{y}}{1+r_{t+1}} .
$$

Similarly it follows for any period $t+j, j \geq 1$, that

${ }^{7}$ Thum and von Weizsäcker (1999) calculate the implicit income tax for several reform scenarios in the German PAGO system. See Beckmann (2000) for an illuminating discussion of the variables on which the implicit tax share will depend. 


$$
S_{t+j} N_{t+j}^{y}=\frac{T_{t+j+1} N_{t+j+1}^{y}}{1+r_{t+j+1}}+\frac{S_{t+i+1} N_{t+j+1}^{y}}{1+r_{t+j+1}}
$$

Inserting (1) and (4) into (3) gives

$$
D_{t}=T_{t} N_{i}^{y}+S_{t} N_{i}^{y}
$$

which can be written as

$$
D_{t}=T_{t} N_{t}^{y}+\frac{T_{t+1} N_{t+1}^{y}}{1+r_{t+1}}+\frac{S_{t+1} N_{t+1}^{y}}{1+r_{t+1}}
$$

when (9) is used. The numerator of the last fraction on the right hand side of (12) can be replaced with $S_{t+j} N_{t+j}^{y}$ from (10) for $j=1$ and the same operation can be done with the numerator of last fraction on the right hand side of the resulting equation when $j=2$ is assumed, similarly for $j=3$ and so on. The result is

$$
D_{t}=\sum_{j=l}^{\infty} T_{j} N_{j}^{y} R_{j}
$$

where $R_{j}$ is the discount factor for calculating the value in period $t$ of a tax paid in period $j$ :

$$
R_{j} \equiv \prod_{k=t+1}^{k=j} 1 /\left(1+r_{k}\right) \text { for } j>t \text { and } R_{t}=1
$$


It is assumed that the elements of the sum in (13) converge, which is the case if, beyond some finite time $j$, the implicit tax revenue grows at a rate which is smaller than, and bounded away from, each period's market rate of interest. As (7) reveals that this condition is basically identical with assuming that the implicit tax is positive beyond some finite point in time, convergence can be assumed without any additional loss of generality.

Equation (13) reveals two useful propositions. ${ }^{8}$

Proposition 1: At each point in time during the existence of a PAYGO system the present value of the implicit taxes to be paid by all subsequent generations equals the value of the implicit government debt.

The second proposition covers a special case of Proposition 1 and follows if it is noted that, according to (3), $D_{0}=N_{0}^{p} P_{0}$ :

Proposition 2: The introductory gain of the first generation of retirees equals the present value of the implicit taxes that have to be paid by all future generations.

Propositions 1 and 2 demonstrate the nature of the PAYGO system as a zero-sum game among the generations. They show that the burden imposed on the participants of an existing PAYGO system cannot necessarily be attributed to the inefficiency of the system, but may simply be a tax which is necessary to service the implicit government debt which was created with the gift to the first generation.

\footnotetext{
${ }^{8}$ The spirit of Proposition 1 has also been explained by Homburg (1997) with a steady state example where the sum of wages remains constant and the rate of return in the PAYGO system is zero. Proposition 1 needs no assumptions on the time paths of wages, the discount rate, the contribution rate, and the replacement rate other than the convergence condition.
} 
Note that servicing the implicit debt does not mean redeeming it. In fact, since (3) reveals that the implicit debt equals a generation's pension claims which typically grow from one generation to the next, it is clear that the debt will also increase with the passage of time. Thus the debt redemption is negative, which means that the implicit interest burden cannot be fully financed with the implicit tax and needs to be partially covered with new implicitly borrowed funds. Nevertheless, it is still true that the implicit debt equals the present value of all future implicit tax payments up to the very last cent.

\section{The Transition Question}

Let us now consider the transition problem which is at the center of today's policy debate about the pension problem. In principle, in the PAYGO system all future generations will participate in servicing the implicit debt created with the gift to the introductory generation. (Indeed, it follows from (7) and (6) that the implicit wage tax rate would even stay constant if the economy were on a steady state growth path where the market rate of interest is constant and where the contributions and the sum of wages grow at the same constant rate.) What happens to the tax burden when the PAYGO system is replaced with a funded system where a person's pension contributions are invested in the capital market so as to give this person a fair pension, one whose present value equals the investment outlay?

Since the existing pension claims will have to be respected and a person's contributions are fully used for his or her own pension, an explicit tax is necessary to finance the existing pension claims. A radical reform that maximizes the transition speed makes it necessary to impose the tax on the current working generation. The volume of this tax is equal to the implicit government debt and hence equal to the present value of the implicit taxes that would have been paid by all future generations had the PAYGO system continued to exist. In fact, this gives a straightforward result. 
Corollary of Proposition 1: A rapid transition to a funded system makes it necessary to redeem the implicit debt immediately. Such a reform concentrates the tax burden implicit in the PAYGO system in one period, but does not reduce its size.

Many authors have seen the difficulty of imposing a double burden on the transition generation and have therefore advocated a more gradual transition by using public debt as a smoothing device. Some part of the burden, it is argued, should be imposed on the current working generation and the rest should be financed with long term government debt to be serviced by all future generations. Will this policy be able to reduce the present value of the tax burden?

To answer this question only a few formal steps are necessary. Let $D_{\text {, }}^{e}$ and $T_{1}^{e}$ denote the explicit government debt and the explicit tax used for servicing the debt per member of the working generation in period $t$. From the basic equation of motion

$$
\left(D_{t}^{e}-T_{t}^{e} N_{i}^{y}\right)\left(1+r_{t+1}\right)=D_{t+1}^{e}
$$

it follows that

$$
D_{t}^{e}=T_{i}^{e} N_{i}^{y}+\frac{D_{t+1}^{e}}{1+r_{t+1}},
$$

and in general it holds for arbitrary points in time $t+j, j \geq 1$, that

$$
D_{t+j}^{e}=T_{t+j}^{e} N_{1+j}^{y}+\frac{D_{t+i+1}^{e}}{1+r_{t+j+]}} .
$$

Substituting $D_{i+1}^{e}$ in (16) with the respective value that (17) gives for $j=1$ one gets 


$$
D_{i}^{e}=T_{i}^{e} N_{i}^{y}+\frac{T_{t+1}^{e} N_{i+1}^{y}}{1+r_{t+1}}+\frac{D_{t+2}^{e}}{\left(1+r_{t+1}\right)\left(1+r_{t+2}\right)}
$$

and repeating this operation with $D_{t+2}^{e}$ in (18) using (17) with $j=2$ and so on with successively higher values of $j$ results in the expression

$$
D_{t}^{e}=\sum_{j=1}^{\infty} T_{j}^{e} N_{j}^{y} R_{j}
$$

where $R_{j}$ is again the market discount factor defined in (14) and where again a convergence of the discounted sum of taxes has to be assumed. This expression resembles (13) perfectly, and when $D_{t}=D_{t}^{e}$ is chosen, the following proposition is obvious.

Proposition 3: A policy of converting the implicit debt into an explicit debt and distributing the burden of this debt over the future generations by means of an appropriate redemption policy will not result in a reduction of the present value of the tax burden. Whatever the chosen time pattern of the tax burden is, its present value is always equal to the present value of the implicit tax burden in the PAYGO system.

It would even be possible to replicate the time paths of the implicit tax burden and the implicit debt in the PAYGO system exactly. This can be seen by developing the equation of motion for the implicit government debt. Deriving $D_{t+1}=N_{t+1}^{y} C_{t+1}$ from (1) and (3), inserting this expression into (11) while using (8), and rearranging terms yields

$$
\left(D_{t}-T_{1} N_{1}^{y}\right)\left(1+r_{1+1}\right)=D_{t+1}
$$


A comparison between this equation and (15) shows that a policy of equating the time path of the explicit tax with the one of the implicit tax in the PAYGO system will generate exactly the same time path for the government debt, too. Thus another result can be stated.

Proposition 4: With an appropriate borrowing strategy it is possible to design a transition to a funded system which perfectly mimics the time paths of the implicit tax and the implicit debt in an ongoing PAYGO system.

Given these results, some of the usually quoted reasons for a transition to a funded system do not seem overwhelmingly compelling. Such a transition could change the time path of the tax burden but not the burden itself. The PAYGO system evenly distributes the financial burden resulting from the gift to the introductory generation over all generations. Neither Musgrave's inter-generation equity principle nor more sophisticated welfare arguments for tax smoothing suggest that it would be wise to shift this burden to the shoulders of the current generation as could be done with the introduction of a funded system.

Although these results do suggest some straightforward welfare implications, they should be interpreted with some caution since they have been derived from a partial analytic approach. While it was not necessary to assume a steady state, all present value comparisons were made given the time path of the market rate of interest. The exogeneity of the time path would be strictly justified in a small open economy, but not otherwise. In general, a redistribution of incomes between the generations will change the growth path of the economy and the time path of the marginal product of capital. The strict present value equivalence between the maintenance of the PAYGO system and the transition to a funded system will then no longer hold. The equivalence will only hold if the comparisons are made with the same set of factor prices. From a welfare perspective this is not as big a problem as it 
might appear at first sight. If the transition to a funded system is a lump sum redistribution between different generations, then the endogenous reaction of factor prices will not, in general, be able to generate a Pareto improvement. For such a possibility to occur it would be necessary for the impoverished generations to gain more from the endogenous change in factor prices than they lose by being burdened with an additional tax.

\section{Three Equally Unconvincing Reasons for a Transition to a Funded System}

Despite this result, it is not impossible to construct models of the transition from a PAYGO system to a funded system that predict genuine Paretian efficiency gains. ${ }^{9}$ However, the economic mechanisms responsible for such results may not always be closely related to the funded system as such and may also be available without the introduction of a funded system.

\subsection{Capital Income Taxation and Growth Externalities}

As was shown, the transition to a funded system can be used to concentrate the implicit tax burden in earlier periods of time. Under a variety of plausible assumptions that deviate from the plain Ricardian equivalence view, this would reduce private consumption in earlier periods and would hence increase aggregate savings and investment, thereby stimulating economic growth. ${ }^{10}$ More growth will not necessarily imply a welfare increase, given that there is such a thing as an optimal growth path. However, when the rate of return to capital

\footnotetext{
${ }^{9}$ Cf. Feldstein (1997) and Kotlikoff (1996) as well as the literature mentioned in the introduction.

${ }^{10}$ Among the possibilities one can list the following.

1. If the explicit tax is a consumption tax with a declining rate, households shift consumption to the future and increase their savings.

2. Households which are liquidity constrained and would like to borrow against future income, but cannot, will reduce their present consumption.

3. Households which save but make no bequests to their children, must react to the squeeze of their lifetime budget constraints and consume less during their lifetimes.

4. Concentrating the tax burden on earlier periods means redistributing it between long lived dynasties and short lived ones, whose chain of descendents is interrupted after the first or only a few generations. Since short lived dynasties have a higher marginal propensity to consume per period with regard to wealth transfers than long-lived dynasties do, this redistribution reduces aggregate present consumption and increases saving.
} 
exceeds the households' rate of time preference and discount, the additional capital accumulation resulting from a transition to a funded system may increase the wealth and welfare of the economy.

One potential reason for a divergence between the rate of discount and the rate of return to capital is capital income taxation. Households equate their rate of time preference to the net-of-tax interest rate, and firms equate the marginal value product of capital to the cost of capital which, in the presence of capital income taxation, exceeds the net-of-tax interest rate. The rate of interest in the above formulae, $r$, is in this case the net-of-tax market rate of interest, because it is this rate at which households can transfer resources to the future and at which the government can borrow. If the transition generates additional savings, this will not, at the margin and in itself, change private wealth or welfare, but it will give the government an extra tax revenue which could then be distributed to everyone. With this distribution, private wealth and private welfare would increase. ${ }^{11}$

It is true that the introduction of a funded system generates welfare gains when the system of capital income taxation is to be taken as given. However, the welfare gains would also be available if the system of capital income taxation itself could be abolished or replaced with a better tax system. For example, the introduction of cash flow taxation would completely eliminate the tax wedge between the marginal product of capital and the rate of time preference and induce an efficient speed of economic growth, while capital owners would bear the burden of this form of taxation. ${ }^{12}$ In the presence of cash flow taxation, the extra growth generated by a transition to a funded system would not increase the tax revenue and would not be welfare enhancing.

Capital income taxation drives a wedge between the marginal product of capital and the consumer rate of time preference, and it implies that more growth is welfare increasing

\footnotetext{
IJ See Siebert (1998, p. 21 ) for an approach using this argument.

${ }^{12}$ See Meade Committee (1978) and Sinn (1985).
} 
because the accumulation of capital generates positive fiscal externalities through the government budget. Other types of positive externalities associated with the accumulation of capital, which also drive wedges between the social marginal product of capital and the social rate of time preference, include the spill-over of technological knowledge among innovating firms as is emphasized by modern growth theory ${ }^{13}$ and altruistic utility effects among families such as those on which the Isolation Paradox ${ }^{14}$ is based. These externalities, too, would imply that private capital accumulation is too low and that the additional growth generated by a transition to a funded system is welfare improving. However, once again the question is whether the accumulation of capital might not be accelerated in other ways. Generating growth through the funded system is a second best policy move which cannot, in itself, remove the wedge between the social and private returns to capital. A first best policy move that abolishes this wedge would be the introduction of an investment subsidy such as the Investment Tax Credit or a program to support private savings.

Apart from that, however, it is not clear whether capital formation is really associated with positive externalities. Insecure property rights in developing countries imply that natural resources are transferred too quickly into man-made capital, ${ }^{15}$ and Veblen-type preferences based on relative income positions imply that the market process generates too much economic growth. ${ }^{16}$

Summarizing, it seems fair to say that the case for a funded system on the grounds that it mitigates the externality problem by stimulating economic growth is not particularly compelling, because it is not clear whether, on balance, there are positive growth externalities and because there would be more direct means to stimulate capital accumulation if there were.

\footnotetext{
${ }^{13}$ See e.g. Romer (1990).

${ }^{14}$ See Marglin (1963) and Sen (1967).

${ }^{15}$ See Konrad, Olsen, and Schöb (1994).

${ }^{16}$ See e.g. Corneo and Jeanne (1997).
} 


\subsection{Risk Premia in the Stock Market}

A similar argument applies to the relationship between the rate of return to bonds and to stocks. Normally, the rate of return that can be earned in the stock market is higher than the one that can be earned in the bond market. Since the latter is used for private and public discounting, an increase in saving that leads to a stock market investment will, it appears, increase private wealth and welfare.

However, this appearance could be deceptive, since an investment in stocks incurs more risk than an investment in bonds, and risk bearing in itself is a disadvantage for the households involved. Note that the extra return on stocks is not available with every investment, but on average only. It is a premium for risk taking. If the economy's price of risk taking is appropriately taken into account, the mere fact that stocks have a higher rate of return than bonds does not imply that an increase in investment would be a welfare improvement.

In order for a genuine welfare improvement to occur it would be necessary to demonstrate that the government has access to better risk consolidation devices than private investment funds do and that these devices would not be available without the funded system. While the former does not sound implausible, the latter is definitely false. If the government borrows in the capital market and invests the funds thus received in risk bearing assets, it is able to capture all the gains from its superior risk bearing ability that a transition to a funded system could possibly generate. A transition to a funded system would not be needed to capture these gains.

\subsection{The Labor Leisure Distortion}

In section 6 the pension system was modeled as an intergenerational redistribution device, and the contribution to the system was split into a savings share and a tax share where the latter was the necessary payment to compensate for the introductory gains. In fact, however, many 
pension systems are characterized not only by an intergenerational redistribution, but also by an interpersonal one among the members of the same generation. In the extreme case where the individual pension entitlement is independent of one's own contribution, the full amount of this contribution may be considered a tax.

In this case, large distortions in the labor market must be reckoned with, since the full amount of the contribution drives a wedge between the marginal product of labor and the required marginal compensation of the employees. A transition to a funded system would abolish interpersonal redistribution and reduce the tax burden to the intergenerational redistribution component, provided it is combined with the establishment of individual accounts, as is commonly assumed. As argued by Homburg and Richter (1990) and a subsequent paper by Homburg (1990) this is a potential for welfare improvements.

Again, however, as was demonstrated by Fenge (1995, 1997), this advantage has little to do with the funded system as such. ${ }^{17}$ For one thing, even a funded system could, in principle, be run on a collective basis, where a person's pension is unrelated to his or her savings. For another, individual accounts could easily be combined with the PAYGO system. ${ }^{18}$ Indeed, Germany has had such a system since 1957, and Sweden has recently moved further towards it. In Germany, a person's pension is almost proportional to his or her contributions. ${ }^{19}$ Employees in Germany are less attracted by the black market than in other countries, because they know that they can accumulate pension claims when they declare their incomes. $^{20}$

\footnotetext{
${ }_{18}^{17}$ See also Brunner (1996) and Buchholz (2000) for illuminating discussions of this problem.

${ }^{18}$ This issue was extensively discussed in Diamond (1999).

19 The degree of proportionality is not perfect insofar as the timing of contributions during one's lifetime and early retirement are not reflected in an actuarially fair manner. However, if $A$ works the same years and retires at the same point in time, but earns and contributes always twice as much as $B$ does, he will also receive a pension which is twice as high as that of B. See Wrede (1999) for a welfare analysis of alternative earnings profiles in the context of a Pareto improving transition.

${ }^{20}$ According to a study by Schneider and Enste (2000) Germany's share of black market activities is below the OECD average.
} 
When there are individual accounts, then the above analysis fits an individual's decision problem well. We simply have to assume that the contributions, taxes and savings introduced above are average values and that a person who makes $z \%$ of the average contribution will receive a pension which is $z \%$ of the average pension. In this case, the implicit tax share $\tau$ is a marginal, as well as an average, share in the contributions.

Assume that the individuals in the above model may differ and that

$$
X_{t}=\int X_{1}(i) f(i) \mathrm{d} i \text { for } X_{t}=P_{t}, C_{t}, T_{t}
$$

where $X_{t}(i)$ is the pension, contribution, and tax, respectively, for an individual of type $i$, $f(i)$ is the frequency density function for the alternative types, and $X$, is the corresponding average over all members of the pension system. Suppose individual $i$ 's contribution to the pension system in period $t$ is

$$
C_{t}(i)=c_{t} \alpha_{1}(i) w_{l}(i)
$$

where $c_{l}$ is the uniform contribution rate, $\alpha_{t}(i)$ is his labor supply and $w_{l}(i)$ is his wage rate. Then it follows that individual $i$ 's tax burden is given by

$$
T_{t}(i)=\tau, C_{,}(i)
$$

and that the marginal and average tax burden on working time is 


$$
\frac{\partial T_{,}(i)}{\partial \alpha(i)}=\frac{T_{t}(i)}{\alpha(i)}=\tau_{,} c_{1} w_{l},
$$

where $\tau$, is still given by (7).

Given the time path of the market rate of interest, the model of sections 4-6 remains true regardless of these extensions. In particular, the present value of the implicit tax will continue to equal the present value of the explicit tax that would have to be raised under a funded system. It is true that a change in the time pattern of the tax burden that is typically associated with a transition (unless the case of Proposition 4 applies) would probably cause the time path of the average labor supply to react and would therefore change the time path of the labor tax base. However, this would not affect any of the propositions derived above since they refer to the time path of the implicit aggregate tax revenue rather than that of the tax rate. Thus, although the time path of labor supply may change after a transition, the present value of the labor tax revenue will have to cover the government debt implicit to the existing PAYGO system under all circumstances.

The welfare implication of this result is not trivial since it depends on which definition of a welfare optimum is adopted, what kind of altruistic links between the generations are assumed and which possibilities for private intergenerational resource transfers are allowed. Disregarding intergenerational altruism and resource transfers, and referring to the strict Pareto criterion, Fenge was able to show that, despite an endogenous labor supply reaction, the PAYGO system is Pareto optimal. By the spirit of his argument it would be possible to demonstrate that any transition strategy from a PAYGO system towards a funded system which makes full use of the possibilities of explicit public borrowing is Pareto optimal, too, and that no deviation from this strategy is a Pareto improvement.

It is well-known, in general, that the strict Pareto criterion in connection with the assumption that parents do not care for their children makes Pareto improving policy moves 
difficult to achieve in an intergenerational setting, and it is therefore not very often used in welfare theoretic model building. The tax literature, for example, typically assumes some sort of intergenerational welfare function with altruistic links between the generations. In such a setting, an optimal time path of the wage tax rate, $\tau_{t} c_{t}$, could be derived which minimizes the utility loss of a representative dynasty given that a present value of tax revenues large enough to redeem the pre-existing implicit debt is collected. ${ }^{21}$

In principle, it is conceivable that there is a debt-using transition path towards a funded system which generates more dynastic utility than a continued PAYGO system. However, a plain and rapid transition to a fully funded system is very unlikely to be such a path. On the contrary, the concentration of the inevitable wage tax burden on only one generation is probably not an optimal strategy, when reasonable assumptions about dynastic preferences are made. As the excess burden of a tax is, to the first order of approximation, a quadratic function of the tax rate, a broad tax base is typically preferable to a narrow one. A continuing PAYGO system has a very broad base because it consists of the wage incomes of all subsequent generations. With a sudden transition to a funded system, the tax base is the wage income of one single generation only. Thus, under normal circumstances, in an economy that is close to a steady state, it seems that the time path of the labor tax rate is much closer to the optimum when the PAYGO system is continued than in the case where it is replaced with a funded system.

A reduction in the excess burden which results from the need to repay the implicit government debt is conceivable, however, if labor income as such is given up as the tax base. If a less distortionary tax base than labor income can be found, welfare improvements may, of course, be possible. However, this possibility does not really lend support to a transition to a

\footnotetext{
${ }^{21}$ With double-sided altruism the best policy would be that the parent generation disclaims their pensions and the system is abolished completely. The children could then look after their parents themselves with no labor-leisure distortion being involved. However, when parents care for their descendants, and not the other way around, it is
} 
funded system since it would also be possible to choose the less distortionary base for the contributions to the PAYGO system.

\section{Another Reason for a Partial Transition to a Funded System}

The previous sections could be understood as a plea for maintaining the PAYGO system, but, in fact, they are just a quest for better arguments for the introduction of a funded system. Despite the weakness of the quoted arguments in favor of the funded system a stronger case for such a system can be made when the imminent crises of the pension systems of the western world are taken into account. These crises reflect radical changes in the transfers between the generations, including the transfer enforced by the PAYGO system and the voluntary resource transfer to the subsequent generation which takes place in the form of child rearing and educational expenses.

In most of the more developed OECD countries birth rates have declined considerably over the last few decades and medical progress is continually increasing life expectancy. The result is a sharp increase in the old-age dependency ratio, i.e. the ratio of people 65 years or over to the number of younger people 15 years and upwards. Figure 3 shows the problem for four typical countries, France, Germany, Japan, and the US. Within a century, from 1950 through 2050 , the ratio increases roughly threefold. For every pensioner a member of the working age had to nourish in 1950 , there will be three pensioners in 2050 if labor force participation and retirement conditions do not change. 
Figure 3: The old-age dependency ratio for four industrialized countries

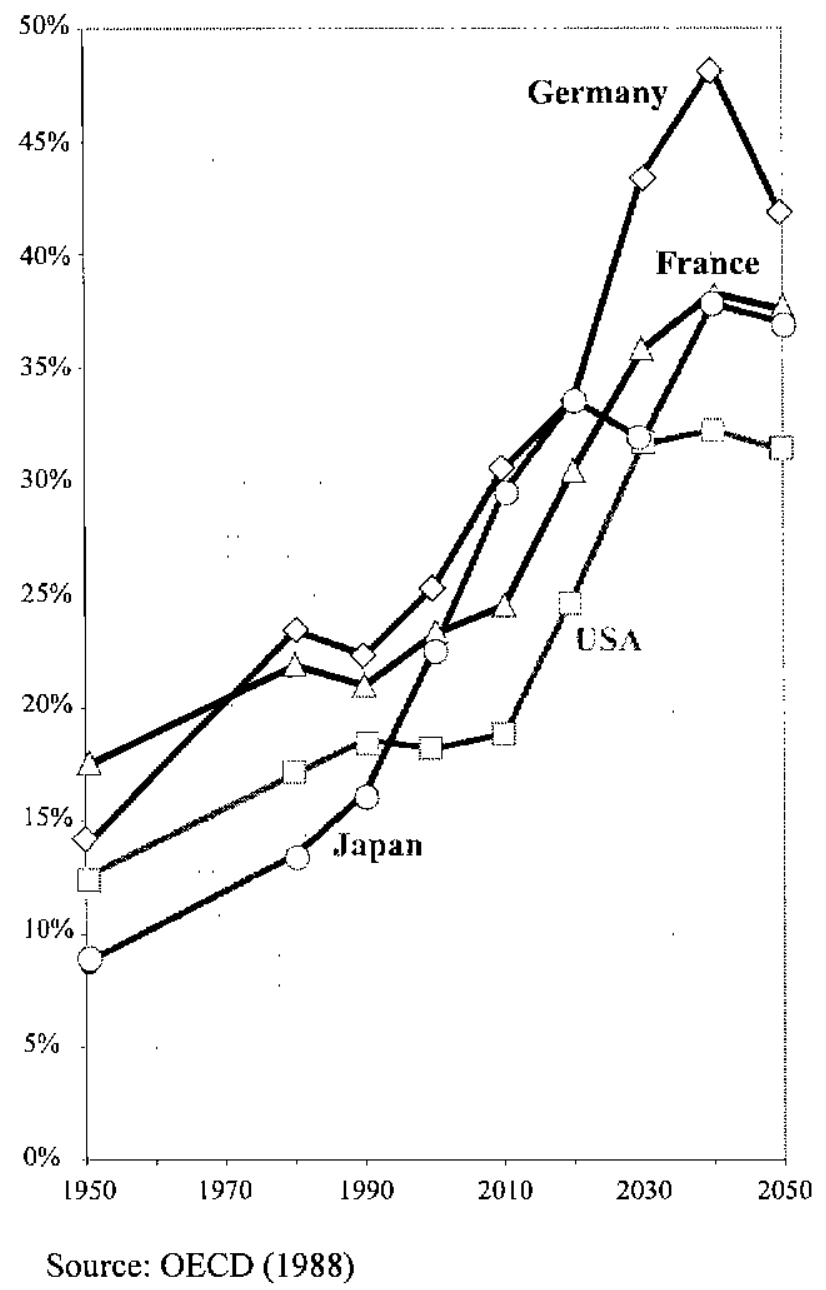

The figure shows that the situation is particularly severe in Germany. There the old age dependency ratio increases from $14 \%$ to nearly $50 \%$ within a century. The reason for this dramatic development is to be sought primarily in the changed fertility rates. In the last century, Germany had the third highest birth rate in Europe, now it has the third lowest one, only surpassed by Spain and Italy. Ten Germans have less then seven children over their lifetimes. Small wonder that the PAYGO system encounters serious problems.

The present German old-age dependency ratio will double, or more than double, up to 2035. Given the replacement ratio - the ratio of an average pension to an average wage income - this would mean doubling the contribution rate from the present $20 \%$ to $40 \%$ of 
wages, and, given the contribution rate, it would mean halving pensions in relation to working income. In 1992, the German parliament introduced substantial future pension cuts, but even they will not be able to prevent the contribution rate rising towards $30 \%$ in the crucial thirties of the next century. In any case, a major crisis of the pension system must be expected.

This leads to an argument in favor of a partial funding of the pension system. In the PAYGO system people expect to receive a pension from their children, but, as there are not enough children, they need a second source for their pension. ${ }^{22}$ Savings invested in the capital market could be such a source. If retirees receive a pension from their savings in addition to receiving one from their children, they can avoid over-burdening their children and nevertheless secure a decent life in old age. ${ }^{23}$

It is true that with such a solution today's working generation would have to bear the frequently cited 'double burden' because they have to nourish the old with their PAYGO contributions and to finance part of their pensions themselves. However, if the cause of the pension crisis is taken into account, there is nothing strange or unusual in this double burden that would provide an argument against funding the pensions.

In order to be able to consume in old age and enjoy a decent retirement life, a working generation has to save or to raise children who will later be able to pay them a pension. Or, to put it more bluntly, the working generation has to invest in real or in human capital. If it does not invest in either real or human capital, it will have to starve because nothing breeds nothing. It has always been the case, and will never be otherwise, that the working generation has to bear a double burden: raising children and paying for the old. Today's working generation has preferred not to raise as many children as previous generations did and it has

\footnotetext{
${ }^{22}$ Werding (1999) has argued that the PAYGO system is a funded system, too, except that funding is based on human rather than real capital. His view also lends support to the considerations developed below. Cf. also Werding (1998) and Sinn (1997,1998a).

${ }^{23}$ An alternative would be to increase the number of immigrants more than was already assumed for the calculations underlying figure 3 , for immigrants will indeed generate a huge net fiscal externality in favor of the
} 
thus decided not to maintain the usual size of the relative voluntary resource transfer to the subsequent generation. Children just don't play the role in everyday life as they used to do, and women no longer sacrifice their careers for having large families. Children come later and in fewer numbers; less time in the course of a mother's live is devoted to their education. ${ }^{24}$ Even the "dink" family with dual incomes and no kids has become an established way of organizing lives. This is the main reason for the pension crisis and a strong motive for introducing a funded pension system. Given that people saved the education expenses and caused the crisis, they may well now be asked to invest the free money in the capital market instead of spending it on additional consumption. It is true that the investment for their own pension is a double burden, but it is the same double burden which they would have had to bear with a continuous development of the population anyway.

It is useful to rethink this argument in terms of the implicit tax which is part of the PAYGO contributions. Return for this purpose to the overlapping generations model used above and consider the current generation of pensioners, the generation of their children who are currently in working age and the generation of grandchildren as well as subsequent generations. If all generations have as many children as was usual in earlier times, they will all bear the normal child rearing costs, will all receive a normal pension and will all pay the normal implicit tax with their pension contributions. Suppose, however, that today's working generation has fewer children while the other generations' reproductive behavior remains unchanged. This will not alter the aggregate present value of the implicit tax to be paid, but fewer people are available to shoulder its burden. One generation at least will have to bear a higher implicit tax in per capita terms, but who should that be?

domestic population (see Sinn 1997). However, the pension problem is only one of many aspects an active immigration policy would have to take into account.

${ }^{24}$ Public child rearing expenses, too, seem to be lower in countries whose fertility rates are low. As casual empirical evidence it may be noted that Germany not only has one of the lowest fertility rates in the world but, among the OECD countries, also the one of the lowest shares in GDP spent on public education. The share is much lower than in the US, for example. See OECD (1996, p. 60). 
At first glance, dynastic-allocative or Musgravian inter-generation equity considerations seem to suggest a policy of tax smoothing over the generations: it seems reasonable to require that all generations including the current generation of pensioners share the extra per capita tax burden. In practical terms, this could imply ${ }^{25}$

i) a cut of today's pensions along with a reduction in today's contribution rate,

ii) an over-proportional cut of the pensions expected by today's working generation and

iii) an increase in the next working generation's contribution rate.

However, this conclusion can only be drawn if the saved child rearing costs from which the current working generation benefits are neglected. Taking these savings into account shows that the current working generation would gain from a policy of implicit tax smoothing at the expense of their predecessors and descendants. Implicit tax smoothing is not burden smoothing, because implicit taxes are only part of the burden that a well-functioning PAYGO system imposes on the working generation.

Focusing on the overall burden of a generation in terms of the sum of its implicit taxes and its child rearing cost, burden smoothing in the presence of the demographic crisis requires the imposition of an extra tax primarily on the current working generation, because this generation saved on child rearing expenses. Thus the pensions to be expected by the current working generation would have to be cut in line with the lower number of their children without alleviating their own pension contributions accordingly.

This is the point where the funded systems comes in. If the PAYGO pensions of those who have fewer children are cut, optimal life cycle planning suggests that at least some of the spared child rearing cost should be invested in the capital market so as to generate additional pensions with the proceeds of this investment. ${ }^{26}$ In other words, it is in the interest of the

\footnotetext{
${ }^{25}$ The German policy of freezing real pensions for a while and moderating the increase in the contribution rate in the next few decades (Nettolohnanpassung, demographischer Faktor etc.) seems to follow this logic.

${ }^{26}$ It can be left open here whether voluntary savings are sufficient or whether savings will have to be obligatory. For this see Homburg (1999) and Fenge/von Weizsäcker (1999).
} 
current working generation to shift the extra part of the implicit tax it has to pay because of its lower number of offspring to a period in its life cycle where it spares the child rearing costs. ${ }^{27}$

Obviously, this kind of reasoning is very different from the efficiency arguments in favor of funded pensions that one finds in the literature. Instead of some fundamental intrinsic inefficiency, which many economists believe to show up in the rate-of-return difference, it is the cause of the demographic crisis itself that calls for a funding. If the economy were on a steady state growth path where a typical family's number of children stayed constant from one generation to the next, the transition from a PAYGO system to a funded system would concentrate the total implicit tax burden, which otherwise had to be borne by all subsequent generations, on the current working generation alone, and this burden seems unjustified since it comes in addition to the normal burden of raising their children. ${ }^{28}$ However, given that the crisis results from the working generation's choice to lower their child rearing expenses, the imposition of a compensatory implicit tax burden is a plausible reaction.

There are important implications for the useful volume of funding. While the (false) rate-of-return argument implies that a full transition is advisable to fully exploit the advantages of the 'better' system, the reason given above can only lend support to partial funding. Funding with real capital is useful to the extent that 'funding' with human capital is lacking. More than that is unnecessary.

Another implication relates to the way the extra implicit tax and the necessary volume of funding could be broken down to the single households within a generation. After all, the reproductive behavior is not homogeneous within a generation. Some households have a

\footnotetext{
27 The case for funding does not apply to the extent that the increase in the dependency ratio can be attributed to rising life expectancy rather than the low fertility rate. If people live longer, but have the usual number of children, there are no spared resources they could save and invest. The appropriate policy reaction would be different. It could include an extension of the retirement age, a cut in annual pensions and higher contribution rates for subsequent generations.

28 According to calculations carried out at CES for the Council of Advisors to the German Ministry of Economics, a full and unmitigated transition to a funded system would immediately raise the sum of PAYGO contributions and the necessary saving to a good $28 \%$ which is also the forecast for the contribution rate in an unchanged PAYGO system for the year 2035. See Wissenschaftlicher Beirat (1998).
} 
sufficient number of children, others have none, some invest in human capital, others don't. It would be in the logic of the burden smoothing argument to cut a household's PAYGO pension in line with the number of children who are missing relative to some target number and to ask this household for compensatory savings to secure its living standard in old age with a self-financed funded pension, without alleviating its contributions to the PAYGO system.

In addition to improving the degree of burden smoothing, tailoring the necessary pension reform to the single households has the advantage of improving the incentive structure for individual fertility choices. The PAYGO system socializes part of the earnings capacity of a household's children in that the contributions that these children will make to the system when in working age will be evenly distributed among all pensioners regardless of the number of children they reared during their lifetimes. It is an open question to what extent this socialization effect has contributed to the decline in birth rates, but it is well founded theoretically and does not seem to be negligible from an empirical perspective. ${ }^{29}$ Cutting PAYGO pensions and replacing them with funded pensions to the extent that a household chooses not to invest in human capital reduces the degree of socialization and mitigates the distortion in the individual fertility choices resulting thereof.

\section{Conclusion}

Politicians want to be right, but scientists want to be right for the right reason. This preference explains why most of the space of this paper was devoted to a discussion of the 'wrong' reasons. It was shown that the PAYGO pension system is not, in its essence, an inefficient insurance device that absorbs economic resources but a zero-sum game between the generations. In present value terms, there is nothing to be gained from a transition to a funded

\footnotetext{
${ }^{29}$ See Nugent (1985), Cigno/ Rosati (1996), Werding (1997), and Sinn (1998b).
} 
system even though the latter offers a permanently higher rate of return. The sum of the implicit and explicit tax burdens that result from the need to respect the existing pension claims is the same under all systems and transition strategies.

This statement had to be qualified in the presence of capital income taxation, risk premia and a consideration of an endogenous labor leisure choice, but nevertheless these modifications were seen not to lend any particular support to the transition from a PAYGO system to a funded system.

The arguably 'true' reason which was offered in the last section of the paper relates to an extended view of burden smoothing when both the tax implicit to the PAYGO system and the cost of child rearing is taken into account. In the presence of the demographic crisis, burden smoothing implies partial funding: where human capital is lacking, and to the extent that it is, real capital could be used to fill the gap.

\section{References}

Aaron, H. (1966): “The Social Insurance Paradox," Canadian Journal of Economics and Political Science 32, 371-374.

Beckmann, K. (2000): "A Note on the Tax Rate Implicit in Pay-as-you-go Public Pension Contributions," Finanzarchiv, forthcoming.

Börsch-Supan, A. (1998): "A Public Pension System on the Verge of Collapse," in: H. Siebert (ed.), Redesigning Social Security, Mohr Siebeck: Tübingen.

Breyer, F. (1989): "On the Intergenerational Pareto Efficiency of Pay-as-you-go Financed Pension Schemes," Journal of Institutional and Theoretical Economics 145, 643-658.

Brunner, J. K. (1996): "Transition from a Pay-as-you-go to a Fully Funded Pension System: The Case of Differing Individuals and Intragenerational Fairness," Journal of Public Economics 60, 131-146.

Buchholz, W. (2000): "Efficiency of Pension Schemes. A Note," mimeo, University of Regensburg.

Corneo, G. and O. Jeanne (1997): “On Relative Wealth Effects and the Optimality of Growth," Economics Letters 54, pp. 87-92.

Diamond, P. (1999), ed.: Issues in Privatizing Social Security, Report of an Expert Panel of the National Academy of Social Insurance, MIT Press: Cambridge, Mass., London, England. 
Feldstein, M. (1995): "Would Privatizing Social Security Raise Economic Welfare?" NBER Working Paper 5281.

--- (1997): "Transition to a Fully Funded Pension System: Five Economic Issues," NBER Working Paper 6149.

Feldstein, M., and A. Samwick (1998): "The Economics of Prefundung Social Security and Medicare Benefits,” in: H. Siebert (ed.), Redesigning Social Security, Mohr Siebeck: Tübingen.

Fenge, R. (1995): "Pareto-efficiency of the Pay-as-you-go Pension System with Intragenerational Fairness," Finanzarchiv 52, 357-363.

--- (1997): Effizienz der Alterssicherung, Physica: Heidelberg.

Fenge, R., and J. von Weizsäcker (1999): "To What Extent are Public Pensions ParetoImproving? On the Interaction of Means Tested Basic Income and Public Pensions," CESifo Working Paper 197.

Geanakopolos, J., O.S. Mitchell, and S.P. Zeldes (1998): "Would a Privatized Social Security System Really Pay a Higher Rate of Return?" NBER Working Paper 6713.

Homburg, S. (1990): "The Efficiency of Unfunded Pension Schemes," Journal of Institutional and Theoretical Economics 146, 640-647.

--- (1991): "Interest and Growth in an Economy with Land," The Canadian Journal of Economics 24, pp. $450-459$.

--- (1997): "Old Age Pension Systems: A Theoretical Evaluation," in: H. Giersch, ed., Reforming the Welfare State, Springer: Berlin, Heidelberg and New York, pp. 233246.

--- (1999): "Compulsory Savings in the Welfare State," mimeo, University of Hannover, forthcoming in Journal of Public Economics.

Konrad, K.A., T.E. Olsen, and R. Schöb (1994): "Resource Extraction and the Threat of Possible Expropriation: The Role of Swiss Bank Accounts," Journal of Environmental Economics and Management 26, pp. 149-162.

Kotlikoff, L. (1996): "Simulating the Privatization of Social Security in General Equilibrium," NBER Working Paper 5776.

Kotlikoff, L., K. Smetters, and J. Walliser (1998): "The Impact of Transiting to Privatized Social Security," in: H. Siebert (ed.), Redesigning Social Security, Mohr Siebeck: Tübingen.

Lüdeke, R. (1988): "Staatsverschuldung, intergenerative Redistribution und umlagefinanzierte gesetzliche Rentenversicherung: Eine andere Sicht der Lasten durch ein negatives Bevölkerungswachstum," in: J. Klaus and P. Klemmer, Wirtschaftliche Strukturprobleme und soziale Fragen, Duncker und Humblot: Berlin.

Marglin, S.A. (1963): "The Social Rate of Discount and the Optimal Rate of Investment," Quarterly Journal of Economics 77, pp. 95-111.

Meade Committee (1978): The Structure and Reform of Direct Taxation. Report of a Committee chaired by Professor J. E. Meade (The Institute for Fiscal Studies), Allen \& Unwin: London.

Niehans, J. (1966): "Eine vernachlässigte Beziehung zwischen Bodenpreis, Wirtschaftswachstum und Kapitalzins," Schweizerische Zeitschrift für Volkswirtschaftslehre und Statistik 102, pp. 195-200. 
Nugent, J. (1985): "The Old-age Security Motive for Fertility," Population and Development Review 11, 75-97.

OECD (1988): Reforming Public Pensions, OECD Social Policy Studies No. 5.

--- (1996): Education at a Glance, OECD: Paris.

Romer, P. (1990): "Endogenous Technological Change," Journal of Political Economy 98, pp. S71-S102.

Schneider, F., and D. Enste (2000): "Shadow Economies around the World - Size, Causes, and Consequences," Journal of Economic Literature, forthcoming.

Sen, A.K. (1967): "Isolation, Assurance and the Social Rate of Discount," Quarterly Journal of Economics 81, pp. 112-124.

Siebert, H. (1998): "Pay-as-You-Go versus Capital-Funded Pension Systems: The Issues," in: H. Siebert (ed.), Redesigning Social Security, Mohr Siebeck: Tübingen.

Sinn, H.-W. (1985): Capital Income Taxation and Resource Allocation, North-Holland: Amsterdam, New York etc.

--- (1997): "The Value of Children and Immigrants in a Pay-as-you-go Pension System: A Proposal for a Partial Transition to a Funded System," NBER Working Paper 6229.

--- (1998a): "Comment on Axel Börsch-Supan," in: H. Siebert (ed.), Redesigning Social Security, Mohr Siebeck: Tübingen.

--- (1998b): "The Pay-as-you-go Pension System as a Fertility Insurance and Enforcement Device," NBER Working Paper 6610.

--- (1999): "Die Krise der Gesetzlichen Rentenversicherung und Wege zu ihrer Lösung," Bayerische Akademie der Wissenschaften (ed.), Jahrbuch 1998, Beck: München, pp. 95-119.

Thum, M., and J. von Weizsäcker (1999): "Implizite Einkommensteuer als Meßlatte für die aktuellen Rentenreformvorschläge," Ifo Discussion Paper 64, Ifo Institute, Munich.

Wissenschaftlicher Beirat beim Bundesministerium für Wirtschaft (1998): Grundlegende Reform der gesetzlichen Rentenversicherung, Bundesministerium für Wirtschaft, Studienreihe No. 99: Bonn.

Werding, M. (1997): "Pay-as-you-go Public Pension Schemes and Endogenous Fertility," mimeo, Department of Economics, University of Passau.

--- (1998): Zur Rekonstruktion des Generationenvertrages, Mohr Siebeck: Tübingen.

--- (1999): "Umlagefinanzierung als Humankapitaldeckung," Jahrbücher für Nationalökonomie und Statistik 218, pp. 491-511.

Wrede, M. (1999): "Pareto Efficient Pay-as-you-go Pension Systems with Multi-Period Lives," Jahrbücher für Nationalökonomie und Statistik 219, pp. 494 - 503. 